\title{
Microbiological changes during the preparation steps of Khliaa Ezir: a traditional cured meat product of Algeria
}

\author{
Hiba-Ryma Boudechicha ${ }^{1}$, Ines Nasri ${ }^{1}$, Zahra Bennaceur ${ }^{1}$, Meriem Sellama ${ }^{1}$, Kahina Hafid ${ }^{1}$, Abdelghani Boudjellal ${ }^{1}$ and Mohammed \\ Gagaoua $^{2 *}$
}

${ }^{1}$ Equipe MaQuaV, INATAA, Université des Frères Mentouri Constantine 1, Route de Ain El-Bey, 25000 Constantine, Algeria

${ }^{2}$ UMR1213 Herbivores, INRA, VetAgro Sup, Clermont université, Université de Lyon, 63122 Saint-Genès-Champanelle, France

\begin{abstract}
Khliaa Ezir is a traditional and popular meat product, which is produced from whole beef, camel, goat or lamb meat. It is an Algerian and a ready to eat meat product that is marinated, cooked and ripened. The product is for numerous months preserved in an earthenware jar at room temperature. Microbiological investigation on Khliaa Ezir during preparation is a prerequisite and to our knowledge, this is the first study, which provide its preliminary microbiological characterization. Thus, the aim of the present work is to study the evolution of the microflora and microbiological safety of Kbliaa Ezir during the main traditional preparation steps. The microbiological counts indicated that Lactic Acid Bacteria (LAB) are the most abundant in the product, namely during the repining and storage period. However, total Coliforms were very low in fresh beef, being eliminated after 3 days of curing. Yeasts and Molds were the highest in fresh beef, and then disappeared after cooking and during the ripening and storage step. None of the pathogenic flora during the whole preparation steps were detected. We think that the cooking temperature applied during thermal treatment $\left(80^{\circ} \mathrm{C}\right)$ contributed to the high hygienic quality of Khliaa Ezir. On another hand, a significant increase in $\mathrm{pH}$ was observed during the storage period to achieve a final $\mathrm{pH}$ of $6.19 \pm 0.01$ at 30 days of storage.
\end{abstract}

\section{Introduction}

Khliaa Ezir is a typical ready-to-eat meat product prepared and consumed in the North East of Algeria. The preparation of Khliaa Ezir is still basically a family art including three well-defined steps: marinade, cooking and ripening and ageing in an earthenware jar (Ezir). The origin of the word is thought to derive from old Arabic, "Khliaa" referring to the storage step in olive oil and fat and "Ezir" to the earthenware jar; the utensil where it is preserved. The particularity of its traditional diagram process is the ripening step in Ezir for more than 1 year and at room temperature [1].

The marinade step is crucial because salt and spices, namely caraway, coriander and garlic, act in concert as bacteriostatic agents leading to the reduction of water content. This would also play an important role in i) the development of the sensory and textural properties and ii) the enhancement of the microbiological safety of the final product $[2,3]$. The microbial ecosystem of cured meat products, whether cooked or not, and simultaneously their quality and shelf life, are influenced by the environment, raw material characteristics, processing practices and storage conditions including packaging and temperature [4].

Investigation of specific spoilage organisms of several cured meat products have been reported in several studies [4-8]. However, to date no study is available on the microbiological characterization of Khliaa Ezir. Thus, there is a need to characterize this traditional and popular meat product of Algeria during the main preparation steps by studying the dynamic microbiological changes that occur. Therefore, the objective of this study was to characterize and follow the evolution of natural microflora of Khliaa Ezir at different steps of its preparation and assess its microbiological safety from raw ingredients to final product.

\section{Materials and methods}

\section{Khliaa Ezir preparation and sampling}

Khliaa Ezir was prepared using the traditional diagram described in Figure 1. Briefly, 9 preparations were conducted using beef Semimembranosus muscle of an average of $2 \mathrm{~kg}$ for each preparation. The fresh beef obtained from a local butcher was aged according to the standard conditions in Algeria. Fresh boneless lean meat cuts after salting and curing (5-8 cm of length, 4-6 cm thick) were marinated in a mixture of spices that contain caraway, coriander and garlic during 7 days before cooking at $80^{\circ} \mathrm{C}$ on water. Finally, the cooked meat was preserved in an earthenware jar (Ezir) and covered with a mixture of melted beef fat and olive oil. From each batch of Khliaa Ezir preparation, samples of fresh meat (at 0 days), marinade samples (1, 3, 7 days), cooked samples, immersed and stored samples (at 10, 20, 30 days) were sampled for microbiological analysis (in triplicate).

\section{Microbiological analysis}

At selected times during processing, $10 \mathrm{~g}$ of each sample were aseptically homogenized with $90 \mathrm{~mL}$ buffered peptone water (AES Laboratories, Combourg, France) for $2 \mathrm{~min}$ using a Polytron homogenizer (Polytron ${ }^{\circledR}$ PT- MR 2100, Kinematica AG, Switzerland).

Correspondence to: Mohammed Gagaoua, UMR1213 Herbivores, INRA, VetAgro Sup, Clermont université, Université de Lyon, 63122 Saint-GenèsChampanelle, France, Tel: 33473624239; Fax: 33473624639; E-mail: mohammed. gagaoua@inra.fr; gmber2001@yahoo.fr

Key words: Khliaa Ezir, ethnic meat product, microbiological changes, Algeria

Received: October 15, 2017; Accepted: November 02, 2017; Published: November 06, 2017 


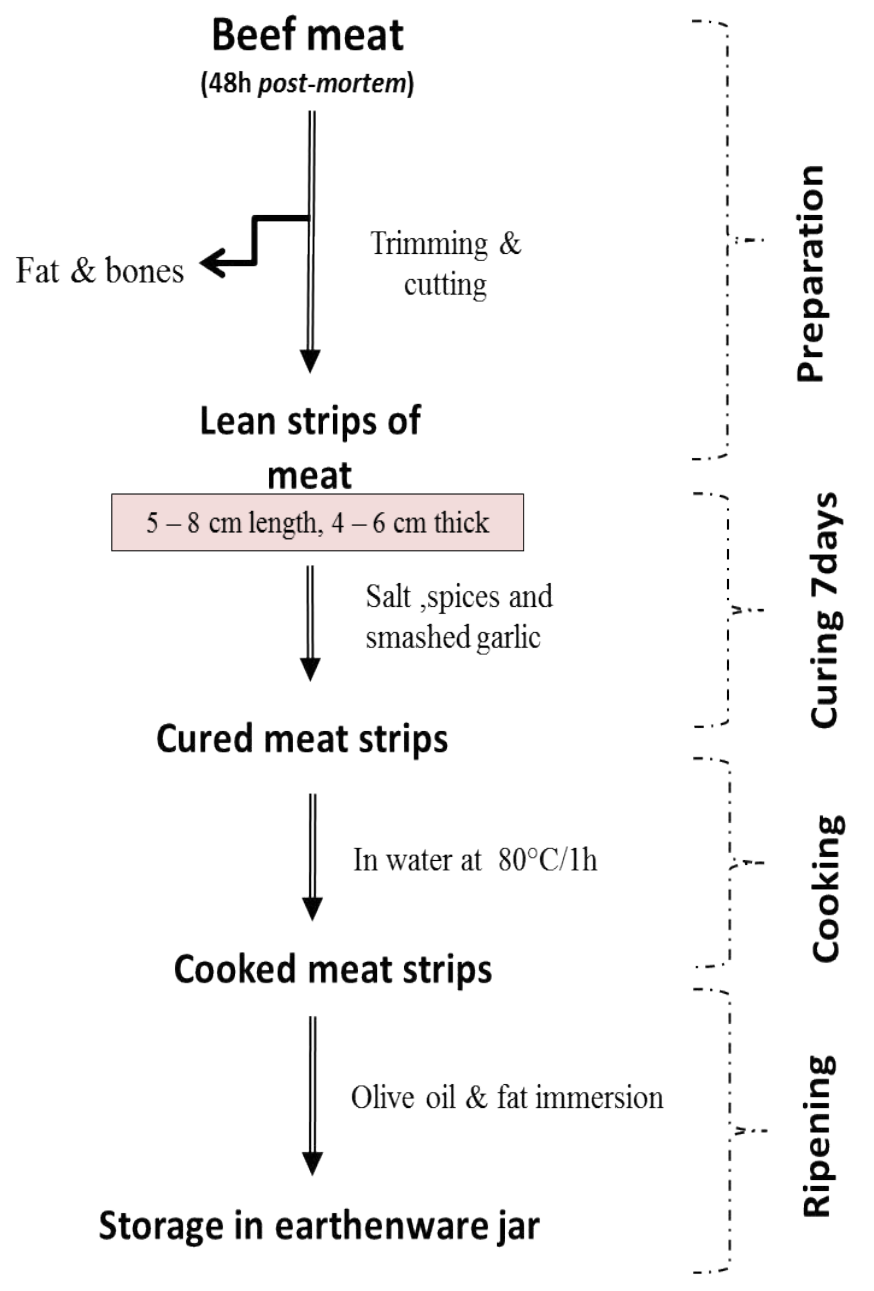

Figure 1. The traditional diagram of Khliaa Ezir preparation [1]

Appropriate decimal dilutions $\left(10^{-1}\right.$ to $\left.10^{-6}\right)$ were prepared. From each sample and on each culture medium, $1 \mathrm{~mL}$ of each dilution was inoculated on different growth media. The microbial groups counted and the conditions of culture are summarized in Table 1 . All the microbiological analyses were carried out in duplicate and the results were expressed as $\log _{10} \mathrm{cfu} / \mathrm{g}$.

\section{pH measurements}

The $\mathrm{pH}$ was measured during the different preparation steps [fresh meat (at 0 days), marinade (1, 3, 7 days), cooking, immersion and storage (at 10, 20, 30 days)] in triplicate. The measurement was done using a $\mathrm{pH}$ meter (PHS-3CW microprocessor $\mathrm{pH} / \mathrm{mV}$ meter, BANTE instrument) after mixing approximately $1 \mathrm{~g}$ of sample with $10 \mathrm{~mL}$ distilled water for $15 \mathrm{~s}$ using a Polytron homogenizer [9].

\section{Statistical analysis}

Data were analyzed using XlStat software (Version 2009.1.01, Addinsoft ${ }^{\circledR}$ ). Analysis of variance and Tukey test were performed to investigate significant differences in microbial count at $P<0.05$ between the different preparation steps of Khliaa Ezir. The results of the statistical analysis are shown as mean values and standard deviation.

\section{Results and discussion}

The evolution of both the microbial population changes and $\mathrm{pH}$ of Khliaa Ezir at the different preparation steps are shown together on the same graph (Figure 2). From the results, total aerobic bacteria counts of fresh beef were relatively low $\left(<5 \log \mathrm{cfu} \mathrm{g}^{-1}\right)$, indicating a good hygienic quality of raw materials. Several authors reported a positive correlation between slaughter conditions and initial contamination of meat $[10,11]$. However, microbiological spoilage and pathogen growth associated with fresh beef meat are directly related to several other factors including the transport conditions, handling practices and processing [12]. During marinade (from day 1 to 7), the development of total aerobic bacteria decreased gradually (Figure 2A). The decrease would be due to the synergic action of salt whose concentration exceeds $9 \%$ and spices. It is well known that salt has a bacteriostatic effect on bacteria [13]. For example, a sodium chloride concentration of 5\% (w/v) inhibits the growth of many Gram-negative spoilage organisms including Pseudomonas. At the final step of Khliaa Ezir preparation, the total aerobic bacteria decrease progressively to reach a lower level after 30 day of ripening $\left(3 \log \mathrm{cfu} \mathrm{g}^{-1}\right)$. This would be assigned to the anaerobic conditions inside earthenware jar caused by melted fat and olive oil (sous-vide conditions). This phenomenon was reported by Cetin, et al. [14] during the preservation of Kavurma, a Turkish meat product. Also, the lack of $\mathrm{O}_{2}$ in the earthenware jar may delay the oxidative deteriorative reactions, and reduce aerobic bacteria growth as earlier reported [6].

The Enterobacteria population was found in low level in fresh beef $\left(4 \log \mathrm{cfu} \mathrm{g}^{-1}\right.$ ) before their disappearance after 3 days of curing (Figure 2B). In this case and as discussed above, the dual action of spicing and salting may be played a great role $[15,16]$. Among the spices used, garlic (Allium sativum) is highly appreciated for the taste it confers to Khliaa Ezir, which is usually added fresh and finely smashed [1,3]. Beside its contribution to the sensory properties of the final product, garlic also has a bactericidal effect, via Allicin, against contaminating flora (Enterobacteriaceae, E.coli, Staphylococcus aureus, Yeasts and Molds) [17]. The feacal Enterobacteria were totally absent during the different steps of Khliaa Ezir preparation. As reported by Castañ, et al. [18], faecal coliforms population is the main indicator of fecal contamination as they determine the hygienic quality of food processing. Furthermore, it has been well established that their growth leads to proteolytic activity that affect texture; also generating amines, ammonia, sulfides, alcohols, aldehydes, ketones, and organic acids that affect flavor $[19,20]$. The significant reduction or even disappearance of these groups of bacteria seems to clearly occur after the cooking step. In accordance, several studies characterizing traditional cooked meat products, reported the pivotal effect of heat treatment on growth of spoilage bacteria and pathogenic organisms $[4,21]$. However, the number and the type of the destroyed microorganisms depend on the internal time/temperature couple. Since thermal treatment of meat can have an impact on the growth of the meat bacteria, controlling temperature and time of cooking is one of the fundamental steps to provide the hygienic quality and extend the shelf life of Khliaa Ezir.

The counts of yeasts and molds showed a strong predominance of yeasts as compared to molds (Figure 2C). The ratio mold/yeast was found to be less than $10 / 100$ in all the experiments. Moreover, the count of this flora is significantly higher than the other groups of microorganisms $(P<0.05)$ in fresh beef. According yeasts is known to be the main causative agent of spoilage [22]. In Khliaa Ezir, their count was found to decrease during the marinade period before their disappearance after 10 days of storage (Figure 2C). The lower yeasts and molds counts is favored by the low water activity values (data not shown) and predominance of LAB (Figure 2D) that exerts an antagonistic action on contaminating flora in concert with $\mathrm{pH}[23,24]$. Re-appearance of yeasts and molds was observed after 30 days of storage to reach $3 \log \mathrm{cfu} \mathrm{g}^{-1}$. We think that these bacteria groups might 
A)

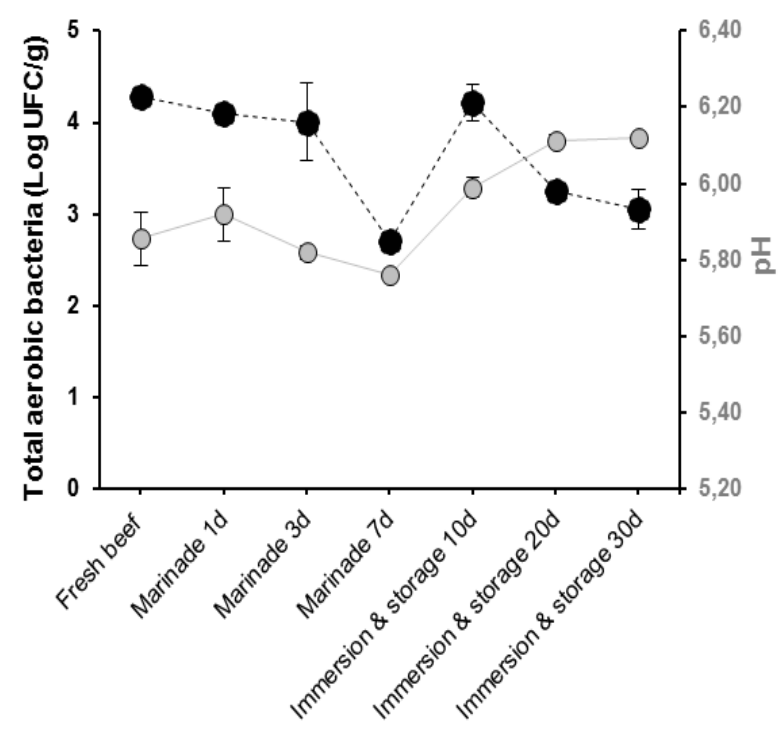

Sampling (time series)

C)

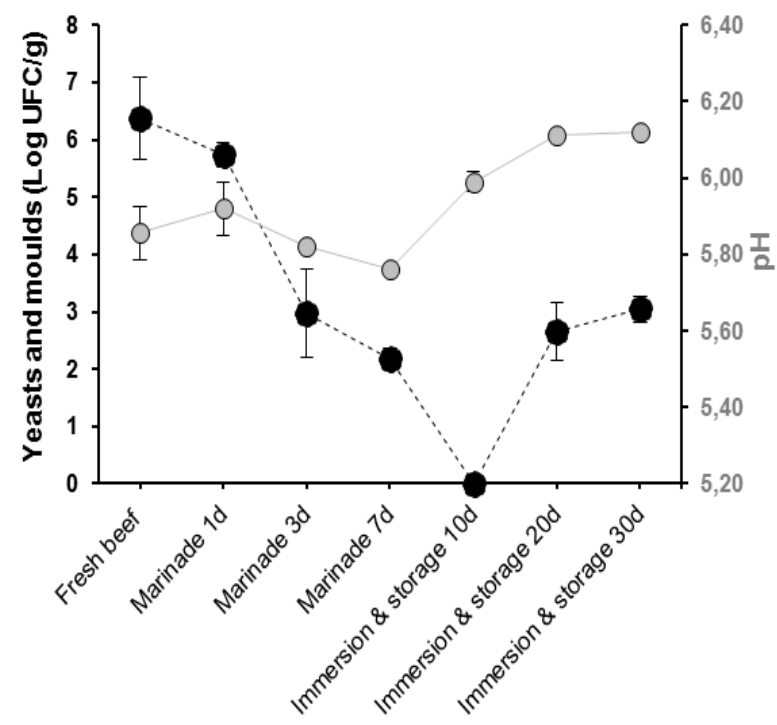

Sampling (time series)
B)

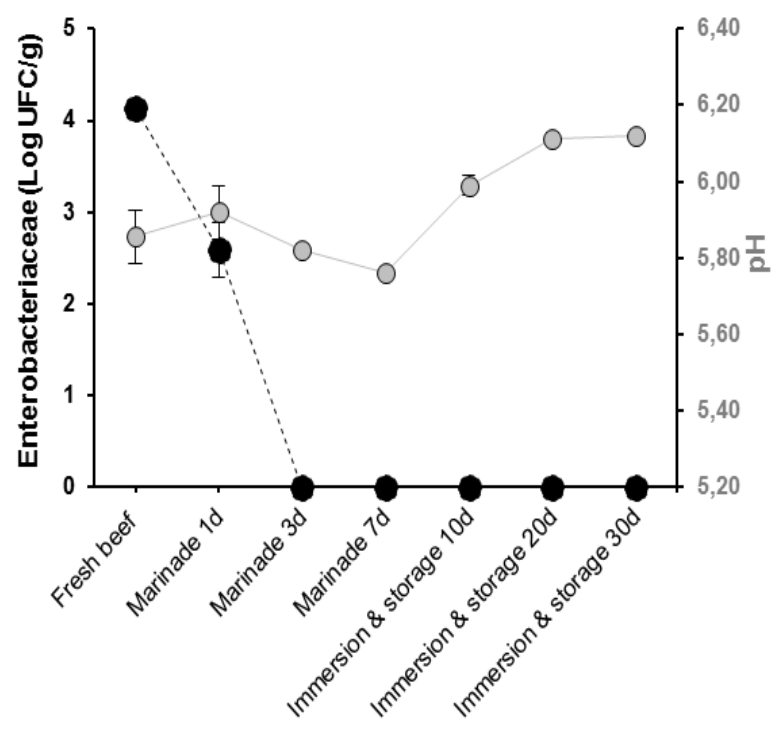

Sampling(time series)

D)

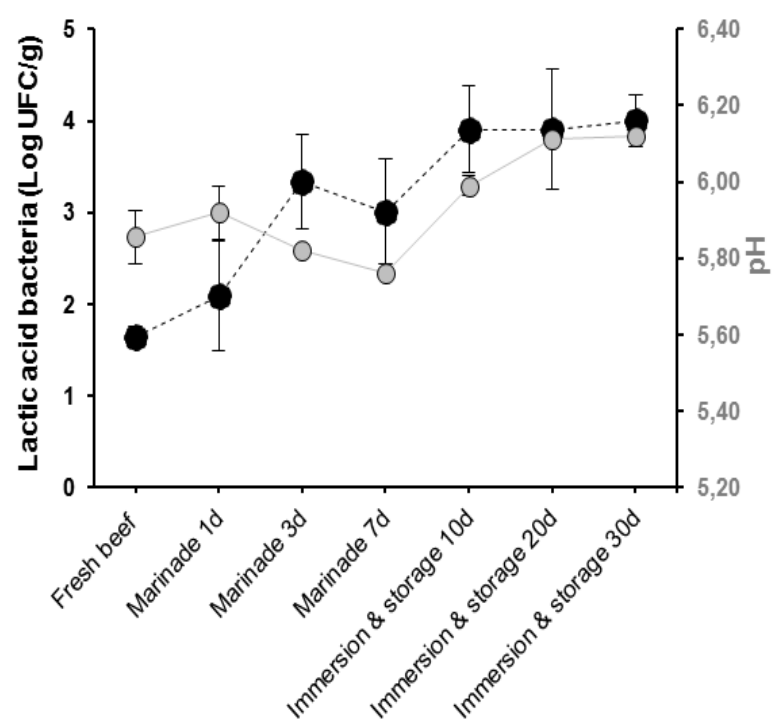

Sampling (time series)

Figure 2. Bacterial groups' evolution (Log CFU/g) and relation with pH during the main Khliaa Ezir preparation steps for A) total aerobic bacteria; B) Enterobacteriaceae; C) Yeasts and Molds and D) Lactic acid bacteria

Table 1. Microbial groups and incubation conditions used in this study

\begin{tabular}{|c|c|c|c|c|}
\hline \multirow{2}{*}{ Microbial groups } & \multirow{2}{*}{ Selective media } & \multicolumn{2}{|c|}{ Incubation conditions } & \multirow{2}{*}{ Sampling time } \\
\hline & & Temperature $\left({ }^{\circ} \mathrm{C}\right)$ & Time (h) & \\
\hline Total aerobic bacteria & PC agar & 30 & 48 & \multirow{7}{*}{$\begin{array}{l}\text { - } \text { Fresh meat } \\
\text { - Marinade (1, 3, } 7 \text { days) } \\
\text { - } \text { Cooking } \\
\text { - Storage and ripening }(10,20 \text {, } \\
\text { 30days) }\end{array}$} \\
\hline Enterobacteriaceae & VRBG agar & 30 & 24 & \\
\hline Fecal Enterococci & VRBL agar & 42 & 24 & \\
\hline Yeast and mold & Malt Extract Agar & 25 & $48-72$ & \\
\hline Lactic acid bacteria & MRS agar & 30 & 72 & \\
\hline Sulphite reducer Clostridium & SPS Agar & 37 & 48 & \\
\hline Salmonella & S-S agar & 37 & 24 & \\
\hline
\end{tabular}

PCA: Plate Count Agar; VRBG: Violet Red Bile Glucose; VRBL: Violet Red Bile Lactose; MRS: Man, Rogosa and Sharpe agar; SPS: Sulfite Polymyxin Sulfadiazine; SS: SalmonellaShigella 
play an important role in the definition of the organoleptic profile of the final product as reported for several traditional meat products [24-27].

The growth rate of Lactic Acid Bacteria (LAB) in Khliaa Ezir during processing is consistent with the $\mathrm{pH}$ profile (Figure 2D). It has been well documented that high acidification rates are usually accompanied by fast and high LAB growth rates [28]. However, LAB in Khliaa Ezir showed a load of $1.64 \log \mathrm{cfu} \mathrm{g}^{-1}$ in fresh beef which increase during ripening to reach a maximum value of $4 \log \mathrm{cfu} \mathrm{g}^{-1}$ after 30 days (Figure $2 \mathrm{D})$. Despite the high rate of $\mathrm{LAB}$, some ripened meat products do not undergo a fermentation period. As reported by Bover-Cid, et al. [29], $\mathrm{pH}$ may increase during the ripening time due to the liberation of peptides, amino acids and ammonia from proteolytic reactions, which limit the fermentation. The shelf life of these products is often not limited by bacteria but by physic-chemical condition, likely temperature and water activity [30].

Sulphite reducing Clostridia and Salmonella were not detected in none of the samples during the whole preparation steps of Khliaa Ezir. We can suggest that the absence of these pathogenic bacteria in Khliaa Ezir would be a consequence of i) the dual action of salt and spices; ii) the cooking temperature and iii) to the conditions of the ecosystem inside the earthenware jar (Ezir). A study performed by Pérez-Rodríguez, et al. [4] on traditional cooked cured meat from countries of West and South-east of Europe, revealed that the amount of nitrite and salt used are enough sufficient to inhibit the outgrowth of endospores, including those of Clostridium and Botulinum. Furthermore, Mayrhofer, et al. [31] observed that Salmonella were not detected in cooked beef at an end-point cooking temperature of $71^{\circ} \mathrm{C}$.

The results of the variance analysis showed that the microbiological levels of the evaluated bacterial groups were statistically similar across the 9 preparations during the whole preparation steps. Thus, a consistency was observed which could validate the findings as the first preliminary microbiological results of Khliaa Ezir. Among the chemical parameters reported in this work, $\mathrm{pH}$ values showed no significant differences $(P>0.05)$ for all samples as a function of different preparation steps.

\section{Conclusion}

This preliminary work showed that dynamic changes of the microbial profile of Khliaa Ezir is related to specific its particular preparation steps which involve first, marinade/curing/salting and second, cooking/ripening steps. The results of the present study showed that Khliaa Ezir could be considered as "shelf stable meat product". The microbiological stability of the final product after 30 day of storage depends on the combination of several factors, mainly on the action of salt and spices, water activity reduction, temperature and time of cooking and the conditions of storage. Further studies are need for overall characterization of Khliaa Ezir and its ecosystem using accurate techniques for an overall inventory of the microbiota.

\section{Acknowledgements}

The support from INATAA Institute is highly acknowledged. The authors would also thank all the persons involved in this project, namely those from MaQuaV team.

\section{References}

1. Boudechicha HR, Gagaoua M, Hafid K, Becila S, Boudjellal A, et al. (2015) Khliaa Ezir, a traditional cured meat product of Algeria: Preparation and characterization In: Proceedings of the 61th International Congress of Meat Science and Meat Technology, pp. 1-4, Clermont-Ferrand, France.
2. Benkerroum N (2013) Traditional fermented foods of North African countries: technology and food safety challenges with regard to microbiological risks. Compr Rev Food Sci Food Saf 12: 54-89.

3. Boudechicha HR, Sellama M, Hafid K, Boudjellal A, Gagaoua M (2016) Adoption of proteomics in traditional meat products: the case of Khliaa Ezir. In: Food futures: ethics, science and culture, pp: 600-606.

4. Pérez-Rodríguez F, Castro R, Posada-Izquierdo GD, Valero A, Carrasco E, et al. (2010) Evaluation of hygiene practices and microbiological quality of cooked meat products during slicing and handling at retail. Meat Sci 86: 479-485. [Crossref]

5. Bennani L, Zenati Y, Faid M, Ettayebi M (1995) Physico-chemical and microbiological characteristics of a dried salted meat product (Kaddid) in Morocco. Z Lebensm Unters Forsch 201: 528-532. [Crossref]

6. Gök V, Obuz E, Akkaya L (2008) Effects of packaging method and storage time on the chemical, microbiological, and sensory properties of Turkish pastirma-A dry cured beef product. Meat Sci 80: 335-344. [Crossref]

7. Soldatou N, Nerantzaki A, Kontominas MG, Savvaidis IN (2009) Physicochemical and microbiological changes of "Souvlaki"-A Greek delicacy lamb meat product: Evaluation of shelf-life using microbial, colour and lipid oxidation parameters. Food Chem 113: 36-42.

8. Casquete R, Benito MJ, Martín A, Ruiz-Moyano S, Aranda E, et al. (2012) Microbiological quality of salchichón and chorizo, traditional Iberian dry-fermented sausages from two different industries, inoculated with autochthonous starter cultures. Food Control 24: 191-198.

9. Lorenzo JM, García Fontán MC, Franco I, Carballo J (2008) Biochemical characteristics of dry-cured lacón (a Spanish traditional meat product) throughout the manufacture, and sensorial properties of the final product. Effect of some additives. Food Control 19: 1148-1158.

10. Aksu MI, Kaya M (2005) Effect of storage temperatures and time on shelf-life of sliced and modified atmosphere packaged Pastirma, a dried meat product, produced from beef. J Sci Food Agric 85: 1305-1312.

11. Ferreira V, Barbosa J, Silva J, Gibbs P, Hogg T, et al. (2009) Microbiological profile of Salpicão de Vinhais and Chouriça de Vinhais from raw materials to final products: Traditional dry sausages produced in the North of Portugal. IFSET 10: 279-283.

12. Petit T, Caro Y, Petit AS, Santchurn SJ, Collignan A (2014) Physicochemical and microbiological characteristics of biltong, a traditional salted dried meat of South Africa. Meat Sci 96: 1313-1317.

13. Papamanoli E, Kotzekidou P, Tzanetakis N, Litopoulou-Tzanetaki E (2002) Characterization of Micrococcaceae isolated from dry fermented sausage. Food Microbiol 19: 441-449.

14. Cetin B, Sert S, Yetim H (2005) Microbiological quality of the kavurma samples marketed in Erzurum, Turkey. Ann Microbiol 55: 27-31.

15. Dadalioglu I, Evrendilek GA (2004) Chemical compositions and antibacterial effects of essential oils of Turkish oregano (Origanum minuti florum), bay laurel (Laurusnobilis), Spanish lavender (Lavan dulastoechas L.), and fennel (Foeniculum vulgare) on common food borne. Food Chemistry.

16. Chung JY, Choo JH, Lee MH, Hwang JK (2006) Anticariogenic activity of macelignan isolated from Myristicafragrans (nutmeg) against Streptococcus mutans. Phytomedicine 13: 261-266.

17. González B, Diez V (2002) The effect of nitrite and starter culture on microbiological quality of "Chorizo"--a Spanish dry cured sausage. Meat Science 60: 295-298.

18. Castañ oA, Fontán MCG, Fresno JM, Tornadijo ME, Carballo J (2002) Survival of Enterobacteriaceae during processing of Chorizo de cebolla, a Spanish fermented sausage. Food Control 13: 107-115.

19. Fernandez-Fernandez E, Rozas-Barrero J, Romeo-Rodriguez MA, Vazque-Oderiz ML (1991) Changes in the physicochemical properties and organoleptic quality of Galician chorizos during curing and after vacuum packing. Food Chemistry 60: 555-558.

20. Rubio B, Martínez B, González-Fernández C, Garci MD, Rovira J, et al. (2006) Influence of storage period and packaging method on sliced dry cured beef "Cecina de Leon": Effects on microbiological, physicochemical and sensory quality. Meat science 74: 710-717.

21. Little CL (1998) The microbiological quality of ready-to-eat dried and fermented meat and meat products. Int J Environ Health Res 8: 277-284. 
22. Limsowtin GKY, Broome MC, Powell IB (2004) Lactic acid bacteria, taxonomy. In Encyclopedia of Dairy Sciences. Roginski H. Oxford, Elsevier, 1470-1478.

23. Lizaso G, Chasco J, Beriain MJ (1999) Microbiological and biochemical changes during ripening of Salchichón, a Spanish dry cured sausage. Food Microbiology 16 : 219-228.

24. Ferreira V, Barbosa J, Silva J, Vendeiro S, Mota A, et al. (2007) Chemical and microbiological characterization of "Salpicao de Vinhais" and "Chouriç, a de Vinhais": Traditional dry sausages produced in the north of Portugal. Food Microbiology 24: 618-623.

25. Geisen R, Lücke FK, Kröckel L (1992) Starter and protective cultures for meat and meat products. Fleischwirtsch 72: 894.

26. Encinas JP, López-Díaz TM, García-López ML, Otero A, Moreno B (2000) Yeast populations on Spanish fermented sausages. Meat Sci 54: 203-208. [Crossref]
27. Ferreira V, Barbosa J, Vendeiro S, Mota A, Silva F, et al. (2006) Chemical and microbiological characterization of alheira: a typical Portuguese fermented sausage with particular reference to factors relating to food safety. Meat Sci 73: 570-575.

28. Malti JE, Amarouch H (2008) Microbiological and physicochemical characterization of natural fermented camel meat sausage. J Food Process Preserv 32: 159-177.

29. Bover-Cid S, Izquierdo-Pulido M, Vidal-Carou MC (2001) Changes in biogenic amine and polyamine contents in slightly fermented sausages manufactured with and without sugar. Meat Sci 57: 215-221.

30. Leistner L, Roedel W (1975) The significance of water activity for microorganism in meats. In R. B. Duckworth (Ed.), Water relations of foods (pp. 309-323). London: Academic Press.

31. Mayrhofer S, Paulsen P, Smulders FJM, Hilbert F (2004) Antimicrobial resistance profile of five major food-borne pathogens isolated from beef, pork and poultry. Int $J$ Food Microbiol 97: 23-29.

Copyright: $(2017$ Boudechicha HR. This is an open-access article distributed under the terms of the Creative Commons Attribution License, which permits unrestricted use, distribution, and reproduction in any medium, provided the original author and source are credited. 